\title{
耳鳴に対する蘇子降気湯の治療経験
}

\author{
卯木 希代子 $\mathrm{a}$ 早崎 知幸 $\mathrm{a}$ 鈴木 邦彦 $\mathrm{a}$ \\ 及川 哲郎a 花輪 壽彦 $\mathrm{ab}$
}

a 北里大学東洋医学総合研究所, 東京, $\overline{1} 108-8642$ 港区白金5-9-1

b 北里大学大学院医療系研究科，神奈川， $=228-8555$ 相模原市北里1-15-1

\section{Two Cases of Prolonged Tinnitus Successfully Treated with Soshikokito}

\author{
Kiyoko UKI ${ }^{\mathrm{a}}$ Tomoyuki HAYASAKI ${ }^{\mathrm{a}}$ Kunihiko SUZUKI $^{\mathrm{a}}$ \\ Tetsuro OIKAWA ${ }^{\mathrm{a}}$ Toshihiko HANAWA ${ }^{\mathrm{ab}}$
}

a Oriental Medicine Research Center of the Kitasato University, 5-9-1 Shirokane, Minato-ku, Tokyo 108-8642, Japan

b Doctoral Program of Medical Science, Kitasato University Graduate School, 1-15-1 Kitasato, Sagamihara-city, Kanagawa 228-8555, Japan

\begin{abstract}
Soshikokito is a Kampo formulation used in the treatment of bronchial asthma, especially in those patients with hot flushes and cold sensation in their feet. But there is also a description in classical textbooks for its usage for the treatment of tinnitus. We report two typical cases of prolonged tinnitus treated successfully with soshikokito. Case 1 was a 70-year-old woman who visited our clinic complaining of tinnitus, dizziness and insomnia. She had a history of bilateral otitis media in her childhood, and had been suffering from tinnitus after being operated for it. The tinnitus had worsened during the three months prior to her first visit to us. After 3 months' treatment with soshikokito with additional shisoyo, her symptoms improved, so much so that after 8 months, she could live her life normally. Case 2 was a 58-year-old man who presented with tinnitus, hearing disturbance and a sense of irritation. He also complained of insomnia and cold sensation in his limbs. After 1 month's treatment with soshikokito with additional shisoyo and bushi, most all of his symptoms resolved. In addition, we also evaluated the clinical efficacy of soshikokito for prolonged tinnitus, retrospectively, and found that it was effective in five out of the ten cases we treated with this formulation. Most of the successfully treated patients presented with hot flushes or cold sensation in their feet. These case reports suggest that soshikokito may be a useful formulation for the treatment of not only bronchial asthma, but also of prolonged tinnitus.
\end{abstract}

Key words : soshikokito, shisoshito, tinnitus

\section{要旨}

数年来の耳鳴に対して蘇子降気湯を投与した症例を経験したので，著効を得た 2 症例の症例呈示と合わせて報告 する。症例 1 は70歳女性。主訴はめまい, 耳鳴, 不眠である。5 歳時の両耳中耳炎手術後より耳鳴があったが, 3 力月前より回転性めまいが出現, 以後耳鳴が強くなり来所した。頭重感, 不眠, 足先が冷えやすい等の症状があり, 蘇子降気湯加紫蘇葉を処方したところ, 服用 1 力月でめまいは改善し，3 力月後には不眠や耳鳴も改善し，8 カ月 後には普通の生活ができるようになった。症例 2 は58歳男性。難聴, 耳鳴を主訴に来所した。5 年前より回転性め まいと右の聴力低下が出現, 進行して聴力を喪失し, さらに 1 年前より左の聴力低下も出現した。近医にてビタミ ン剤や漢方薬を処方されたが聴力過敏・耳鳴が出現した。イライラ, 不眠, 手足が冷える等の症状も認めた。八味 丸料加味を投与したが食欲不振となり服用できず, 気の上衝を目標に蘇子降気湯加紫蘇葉附子に变方したところ,

服用 1 力月で自覚症状が改善し，騒音も気にならなくなった。その後の服用継続にて不眠・足冷も改善した。当研 究所漢方外来において耳鳴に対する蘇子降気湯の投与を行った13例中, 評価可能な10例のうち5例に本方は有効で あった。有効例のうち 4 例は, のぼせまたは足冷を伴っていた。

蘇子降気湯は『療治経験筆記』において「第一に喘急, 第二に耳鳴」との記載がある。数年経過した難治性の耳 鳴にも本方が有用であることが示唆された。

キーワード : 蘇子降気湯, 紫蘇子湯, 耳鳴 
表 1 当研究所の耳鳴に対する蘇子降気湯投与症例

\begin{tabular}{|c|c|c|c|c|c|c|c|c|c|c|c|c|}
\hline 性 & 年齢 & 主訴 & 基礎疾患 & 随伴症状 & 難聴 & めまい & 足冷 & 脈診 & 舌診 & 腹診 & 処方 & 効果 \\
\hline 女 & 70 & $\begin{array}{c}\text { めまい耳 } \\
\text { 鳴 }\end{array}$ & 高血圧症 & $\begin{array}{l}\text { 不眠、 } \\
\text { のぼせ }\end{array}$ & 無 & 有 & 有 & $\begin{array}{c}\text { 沈、結 } \\
\text { 代 }\end{array}$ & $\begin{array}{l}\text { 湿、やや暗 } \\
\text { 紅、舌下静脈 } \\
\text { 怒張、中白苔 }\end{array}$ & \begin{tabular}{|l|} 
腹カやや虚、 \\
腹満、小腹不 \\
仁
\end{tabular} & $\begin{array}{c}\text { 蘇子降気湯 } \\
\text { 加紫蘇葉 }\end{array}$ & $\begin{array}{c}\text { 有効 } \\
\text { (症例1） }\end{array}$ \\
\hline 男 & 58 & 難聴耳鳴 & $\begin{array}{c}x=\text { ニル } \\
\text { 病 }\end{array}$ & \begin{tabular}{|l|} 
不眠、 \\
のぼせ、. \\
聴賞過敏
\end{tabular} & 有 & 無 & 有 & 沈 & $\begin{array}{l}\text { 乾湿中間、 } \\
\text { 紅、無 }\end{array}$ & \begin{tabular}{|l} 
腹力中等度、 \\
心下㿋鞕、 \\
小腹不仁
\end{tabular} & $\begin{array}{c}\text { 蘇子降気湯 } \\
\text { 加紫蘇葉附 } \\
\text { 子 }\end{array}$ & $\begin{array}{c}\text { 有効 } \\
\text { (症例2) }\end{array}$ \\
\hline 女 & 67 & 耳鳴便秘 & なし & \begin{tabular}{|l|} 
腹満、の \\
ぼせ、 \\
便秘、不 \\
眠
\end{tabular} & 無 & 無 & 有 & 沈、虚 & $\begin{array}{l}\text { やや乾、紅、 } \\
\text { 歯痕、薄白苔 }\end{array}$ & \begin{tabular}{|l} 
腹力中等度、 \\
腹満、胸脇苦 \\
満、心下㾘 \\
䩿、小腹不仁
\end{tabular} & 蘇子降気湯 & 有効 \\
\hline 女 & 70 & 難聴耳鳴 & なし & $\begin{array}{l}\text { 顔ほてり } \\
\text { 多汗、舌 } \\
\text { 痛 }\end{array}$ & 有 & 無 & 無 & 弦 & \begin{tabular}{|l} 
湿、暗紅、秛 \\
裂、 薄白
\end{tabular} & $\begin{array}{l}\text { 腹力虚、腹 } \\
\text { 満、胸脇苦 } \\
\text { 満、心下痏 } \\
\text { 鞭、小腹不仁 }\end{array}$ & $\begin{array}{c}\text { 蘇子降気湯 } \\
\text { 加紫穌葉麻 } \\
\text { 子仁 }\end{array}$ & 有効 \\
\hline 男 & 28 & 耳鳴うつ & 高血圧症 & $\begin{array}{l}\text { うつ、首 } \\
\text { 肩こり、 } \\
\text { 飛蚊症 } \\
\end{array}$ & 無 & 無 & 無 & 弦 & 薄白 & $\begin{array}{l}\text { 腹力中等度、 } \\
\text { 腹満、胸脇苦 } \\
\text { 満、 小腹 } \\
\text { 不仁 }\end{array}$ & $\begin{array}{c}\text { 蘇子降気湯 } \\
\text { 加黄惹 }\end{array}$ & 有効 \\
\hline 女 & 56 & 耳鳴 & 乳癌 & のぼせ & $\begin{array}{c}\text { 突発性 } \\
\text { 難聴 }\end{array}$ & 無 & 有 & 沈 & $\begin{array}{l}\text { 乾湿中間、淡 } \\
\text { 紅、薄白 }\end{array}$ & $\begin{array}{l}\text { 腹力中等度、 } \\
\text { 小腹不仁 }\end{array}$ & $\begin{array}{c}\text { 蘇子降気湯 } \\
\text { 加紫蘇葉附 } \\
\text { 子 }\end{array}$ & 無効 \\
\hline 女 & 54 & 鼻閉耳鳴 & 高血圧症 & \begin{tabular}{|l} 
鼻閉 \\
喘息 \\
便秘
\end{tabular} & 無 & 無 & 有 & 沈 & 乾、薄白 & 腹カ中等度 & $\begin{array}{c}\text { 蘇子降気湯 } \\
\text { 加麻子仁 }\end{array}$ & 無効 \\
\hline 女 & 54 & 耳鳴 & 甲状腺腫 & 動悸 & $\begin{array}{c}\text { 有 } \\
\text { (感音性) }\end{array}$ & 無 & 有 & 沈 & $\begin{array}{l}\text { 湿、暗紅、胖 } \\
\text { 大、歯痕、薄 } \\
\text { 白 }\end{array}$ & $\begin{array}{l}\text { 腹力虚、腹 } \\
\text { 満、小腹不仁 }\end{array}$ & 蘇子降気湯 & 無効 \\
\hline 男 & 66 & $\begin{array}{l}\text { 腹満感 } \\
\text { 耳鳴 }\end{array}$ & $\left|\begin{array}{c}\text { 耐糖能異 } \\
\text { 常 }\end{array}\right|$ & 腹満、う & $\begin{array}{l}\text { 突発性 } \\
\text { 難聴 }\end{array}$ & 無 & 有 & 弦 & $\begin{array}{l}\text { 湿、紅、やや } \\
\text { 㭌大、㖪裂、 } \\
\text { 薄白黄苔 }\end{array}$ & $\begin{array}{l}\text { 腹満、小腹不 } \\
\text { 仁 }\end{array}$ & $\begin{array}{c}\text { 蘇子降気湯 } \\
\text { 加紫蘇葉 }\end{array}$ & 無効 \\
\hline 男 & 51 & 耳鳴 & なし & 便秘 & 無 & 無 & 有 & 弦 & \begin{tabular}{|l} 
乾湿中間、 \\
紅、無
\end{tabular} & $\begin{array}{l}\text { 腹力中等度、 } \\
\text { 腹部動悸 }\end{array}$ & $\begin{array}{l}\text { 蘇子降気湯 } \\
\text { 加紫蘇葉 }\end{array}$ & 無効 \\
\hline
\end{tabular}

\section{緒言}

耳鳴は難治性であることが多く，治療に苦慮する ことがしばしばである。蘇子降気湯は『太平恵民和 凨局方』が原典で，足冷と気の上衝を伴う呼吸困難， 慢性気管支炎，気管支喘息などに使用することで知 られている。また，津田玄仙の『療治経験筆記』に おいて「第一に喘急, 第二に耳鳴」とあり耳鳴に対 する投与の記載が見られるが，本方の耳鳴に対する 治療経験は過去に報告がない。今回我々は, 当研究 所漢方外来において耳鳴に対し蘇子降気湯加味を投 与した症例を経験したので, 数年来の耳鳴に対し著 効を得た 2 症例の症例呈示と合わせて報告する。

\section{I . 症例呈示}

$<$ 症例 $1 ： 70$ 歳女性 $>$

主訴：耳鳴，めまい。

既往歴：58歳時より高血圧にて近医通院加療中。

家族歴：特記すべき事なし。

現病歴：5歳時に両耳の中耳炎手術を受けたが,
以後両耳にセミの鳴くような耳鳴が持続していた。 2002年 1 月初旬に上を向いた時に回転性めまいが出 現した。臥床にて改善したがその後は浮動性めまい が 1 週間程続き, 以後耳鳴が増強した。近医にて高 血圧を指摘され降圧薬を追加処方されたが，胸部不 快感が出現し, その後も増強した耳鳴が続くため, 同年 4 月下旬に当研究所漢方外来を受診した。初診 時, 頭重感, 不眠, 足先が冷えやすい, 首・肩のこ り,イライラなどの訴えあり。

身体所見：身長 $162 \mathrm{~cm}$, 体重 $66 \mathrm{~kg}$, 血圧136/84 $\mathrm{mmHg}$ 。

漢方医学的所見：やや赤ら顔で, 足先の泠えあり。 舌は湿, やや暗紅色で中等度の白苔と舌下静脈怒張 を伴う。脈は沈, 腹力はやや虚で腹満と小腹不仁を 認めた。

臨床経過：気の上衝と足の冷えを考慮して蘇子降 気湯加紫蘇葉 $1.5 \mathrm{~g}$ を投与したところ, 投与 20 日後 にはめまいは軽減し, 動悸の自覚も減少した。投与 
3 カ月後, めまいは消失し, 不眠も改善, 耳鳴は減 少した。投与 8 カ月後には, 普通の生活ができるよ うになった。投与10カ月後には耳鳴は気にならなく なり, 睡眠導入剂も減量できた。その後の経過中, 頭重感，不眠が出現し，釣藤散料に転方したところ， 頭重感はややよいが，肩こり，のぼせが再度出現し たため，前方に戻したところ再びのぼせは改善した。 以後蘇子降気湯の投与を継続中である。降圧剂は減 量し，睡眠導入剂も不要になった他，風邪を引きに くくなった，足の冷えが改善した等，全身症状も改 善傾向にある。

$<$ 症例 $2: 58$ 歳男性 $>$

主訴：耳鳴，難聴，聴覚過敏。

既往歴：57歳 狭心症，前立腺肥大。

現病歴：1998年，メニエル病をきっかけに右聴力 低下が出現, 進行し, 右聴力は消失していた。 1 年 前より特に誘因なく左の聴力低下が出現した（疾患 名・検査結果等は不詳)。近医にて六味丸エキス等 を処方されたが症状はあまり改善せず，荊芥連趗湯 エキスに転方されたが，耳鳴が出現して聴覚過敏と なり，耳栓をしないと雑音に耐えられなくなったた め，2003年11月に当研究所漢方外来を受診した。疲 労で耳鳴の増悪があり, 便秘傾向, イライラ, 立ち くらみ，喘鳴，手先がひどく冷える等の症状を認め た。

身体所見：身長 $163 \mathrm{~cm}$, 体重63kg, 血圧120/74 $\mathrm{mmHg}$ 。

漢方医学的所見: 手足の冷え, 下肢静脈瘤あり。 舌は乾湿中間で紅色無苔, 脈は沈, 腹力は中等度で 小腹不仁と左臍傍部圧痛を認めた。

臨床経過：腎虚が主体と考え，八味丸料加釣藤鈎 $4 \mathrm{~g}$ 黄者 $3 \mathrm{~g}$ を投与した。投与 1 力月後, 聴力は軽 度改善したが，食欲不振，胃部不快感が出現して継 続服用困難となったため, 気の上衝と足冷を目標に 蘇子降気湯加紫蘇葉 $1 \mathrm{~g}$ 附子 $2 \mathrm{~g}$ に転方した。転方 1 カ月で耳鳴は減少し，テレビの音が気にならなく なった。2004年 4 月に狭心症で入院し，漢方服用を 中断したところ耳閉感が再出現したが，同年 7 月に 内服を再開し，耳鳴の減少と不眠の改善がみられた。 なお患者の申告によると, 同月の聴力検査で聴力は 以前と不変とのことであった。投与再開 3 力月後に はテレビ, 電車で耳栓が不要となり, 足の冷えも改 善した。6 カ月後, 電話中の耳鳴・不快感も消失し
た。翌2005年11月以降多忙で服用を中断していても しばらく軽快していたが，2007年 4 月頃から再び耳 閉感，耳鳴が出現したため，同年 5 月より同処方を 再開したところ，服用 2 週間で耳閉感は消失し，以 後継続服用中である。

\section{II．症例蓄積研究}

<対象と方法 $>$

当研究所における蘇子降気湯投与症例をついて, 後方視的に検討した。対象は過去 9 年間（1998年 1 月～2007年 3 月）に当研究所を受診し，蘇子降気湯 を 2 週間以上処方され効果判定可能であった症例35 例で，本方投与後自覚症状の改善が認められたもの を有効とした。

<結果>

蘇子降気湯を処方した症例35例中，男性は15例， 女性は20例であり，平均年齢は56.1歳（28-81歳） であった。蘇子降気湯を処方した理由は, 耳鳴が13 例，咳・息切れが 9 例，気管支喘息が 8 例，その他 5 例であった。13例の耳鳴症例のうち, 効果判定が 可能であった10例中 5 例において, 耳鳴症状の改善 が認められた。蘇子降気湯投与10症例を表 1 に示す。 有効例では全例に気逆の症状を伴っていたが，足冷 は認めないものもあった。腹診所見では全例に小腹 不仁を認め，4 例に胸脇苦満または心下㾂鞕を認め た。

\section{考察}

蘇子降気湯の原典は『太平恵民和剤局方』で， 『千金方』には紫蘇子湯の名前で記載が見られる2)。 『太平恵民和剤局方』一切気門において，「男女虚 陽上り攻めて気升降せず，上盛下虚し，膈隹痰多く， 咽喉利せず, 咳嗽虚煩引飲, 頭目昏眩, 腰疼脚弱, 肢体倦怠, 腹肚疠刺, 冷熱気瀉, 大便風秘, 渋滞通 せず，肢体浮腫，飲食妨げあるを治す」 ${ }^{1)}$ とあり，足 冷と気の上衝を伴う呼吸困難，慢性気管支炎，気管 支喘息などに使用することで知られている方剤であ $b^{3)}$ 。

耳鳴に対する古典の記載として, 津田玄仙の『療 治経験筆記』巻之一において，「此の方を用いて効 ある病，第一に喘急，第二に耳鳴，第三に鼻衄，第 四に歯の摇等，第五に吐血，第六に口中腐爛，第七 に水腫脹満，喘気最も強きもの，第八に痰喘強く咳 嗽の証。右の八証，足冷ゆるの証あらば必ず此の方 を用ゆべし。十に八九効をとるべし。」出と記されて 
表 2 耳鳴に対する漢方治療の症例集積研究

\begin{tabular}{|c|c|c|c|c|}
\hline 報告年 & 報告者 & 掲載雑誌 & 漢方方剂 & 結果 \\
\hline 1988 & 池田ら ${ }^{8)}$ & 耳鳴りと臨床 & 大柴胡湯 & 耳鳴22例に対し大柴胡湯を投与し、やや有効以上は 10 例 $45.5 \%$ 。 \\
\hline 1989 & 田ロ & 現代東洋医学 & 苓桂术甘湯 & $\begin{array}{l}\text { 漢方および西洋薬の単独治療で不変であった耳鳴患者51例において苓 } \\
\text { 桂术甘湯と西洋薬の併用療法を追加し、72.5\%の改善であった。 }\end{array}$ \\
\hline 1993 & 西田ら ${ }^{10)}$ & 漢方診療 & 柴朴湯 & $\begin{array}{l}\text { 耳鳴患者50例に柴朴湯エキスを投与し、32例64\%で耳鳴は改善、対照 } \\
\text { 薬群との間に有意差あり。約78\%が投与開始から2週間以内に効果か } \\
\text { 出現。 }\end{array}$ \\
\hline 1994 & 大西ら ${ }^{11)}$ & 耳鼻咽喉科展望 & 牛車腎気丸 & $\begin{array}{l}\text { 多施設症例集積研究において、耳鳴を主訴とする150例に対する牛車腎気 } \\
\text { 丸の有効率 (やや改善以上)は100例66.7\%。 }\end{array}$ \\
\hline 1998 & 岩崎ら ${ }^{12)}$ & 公立能登総合病院医療雑誌 & 釣藤散 & $\begin{array}{l}\text { 耳鳴48例に対する全般改善度は著明改善35.4\%、改善47.9\%、不変 } \\
\text { 16.7\%、悪化なし。 }\end{array}$ \\
\hline 1998 & 齋藤 ${ }^{13)}$ & 耳鼻咽喉科臨床 & 釣藤散 & $\begin{array}{l}\text { 耳鳴 } 40 \text { 例で改善以上は } 60.0 \% \text { だあった。頭痛·高血圧の有無で治療効 } \\
\text { 果に差を認めなかった。70歳以上の高齢者において有意に効果があっ } \\
\text { た。。 }\end{array}$ \\
\hline 1998 & 木田ら & 耳鼻咽喉科臨床 & 柴胡桂枝湯 & $\begin{array}{l}\text { 発症から3カ月以上経過した耳鳴13例に対する柴胡桂枝湯の有効率(やや } \\
\text { 効以上)は } 38.5 \% \text { 。 }\end{array}$ \\
\hline 2001 & 奥野ら ${ }^{15)}$ & 漢方医学 & 牛車腎気丸 & $\begin{array}{l}\text { 慢性の感音性難聴に伴う耳鳴症例28例中有効例は23例 } 82.1 \% \text { 平均 } \\
\text { 内服期間は17.4週 (8-56週)。 }\end{array}$ \\
\hline
\end{tabular}

いる。また『勿誤薬室方函口訣』では,「此方は脚 弱上気を治する方なれども，今の脚気には効すくな し。上気は今の喘急のことにて, 虚気えぶりて喘鳴 する者に効あり。故に後世にて，足冷喘急を目的と して用ゆ, 又, 耳鳴, 鼻皿, 歯摇, 口中腐爛, 咳血, 水腫, 喘満等の症, 足冷の候あれば必ず効あり。 云々」卓とある。

大塚敬節らは「本方は上衝する気を引き下ろすと いう意で，足冷と咳逆上気して呼吸困難するものが 目標。（中略）以上の目標により本方は慢性気管支 炎，喘息性気管支炎，肺気腫などに用い，また古人 は耳鳴, 吐血, 卹血, 歯槽膿漏, 口中腐爛, 走馬疳

(水癌), 水腫, 脚気などに応用した。」卓と記してい る。またその薬効は, 「方中の蘇子, 前胡, 厚朴, 陳皮，半夏はみな上逆する気を降ろし，痰を除くも のである。気が良くめぐれば痰もまたよく順って滞 らなくなる。半夏厚朴湯が原方で気剂に属する。ま たよく表を発し，外の寒を散ずる。当帰は血を潤し 甘草は急を緩める。桂皮は上衝の気を引き下げ る。影とされている。

今回の 2 症例は，耳鳴に足冷，のぼせ，不眠など を伴っており, 気逆の症状が主体と考えられた。症
例 1 は，幼児期からの耳鳴がベースにあり，気逆が 主体と考えられる耳鳴の症状悪化に対して本方が著 効している。また，本方によって，高血圧，不眠な どの症状も改善が得られており, 気逆に随伴する症 状も改善を認めた。経過中，釣藤散料への転方にて 気逆の症状は再発している。釣藤散は肝血不足によ る肝陽化風を伴った気の上衝を目標とするが, 本症 例では小腹不仁や足冷などの所見が認められ, 腎虚 に伴った気逆と考えられた。胸腹部の不快感などの 気滞の症状に対しては, 気の上衝を引き下げる蘇子 降気湯に気をめぐらす紫蘇葉を加味し，効果が得ら れたものと思われた。紫蘇葉は本草綱目に「表を発 し, 気を巡らし，中をゆるめ，痰を消し，・・・㣺 とあり，蘇子降気湯の紫蘇子の代用としても用いら れることのある生薬である。紫蘇子が入っているの で紫蘇葉の加味は不要との議論もあろうが, 当研究 所の経験では紫蘇葉を加味した方が香り，味ともに 服用しやすく，服薬コンプライアンスがよくなる印 象があった。

症例 2 は足の冷えや小腹不仁を伴い, 当初補㹂を 目的に八味丸料を処方したが，地黄剤による消化器 症状を来したため継続服用は困難であった。気の上 
衝が主体であること，足冷等を目標として蘇子降気 湯とし，腎虚・冷え等に対して附子を，順気を目的 に紫蘇葉を加え処方したところ，耳鳴，聴覚過敏な どの諸症状は改善され，不眠や足冷も改善し，著効 を示した。内服中断後, 多忙な生活の中で約 1 年半 後に再発しているが，投与再開後は再び著効が得ら れており，継続投与で症状は消失している。

症例集積研究において有効例 5 例と無効例 5 例を 比較すると，有効例はいずれものぼせや不眠などの 気逆の症状が顕著であり，このような症例に対して は降気作用の強い本方が有効であると考えられた。 また，「足冷の候あれば必ず効あり。」との記載もあ るように，古典においては足冷が目標の一つとされ ているが，無効例の中には耳鳴と足冷を目標に本方 を投与されたものも含まれていた。足冷を伴わなく ても有効な症例も認められており，足冷は本方を用 いる上での重要な指標のひとつではあるが, 気逆の 一症候として捉えるべきであろうと考えられた。腹 診所見では, 無効例と比較すると有効例には全例に 小腹不仁が認められており，また軽度の胸脇苦満や 心下㾂鞕などが目立つ傾向にあった。本方は基本的 には虚弱な人に用いられるが316)，大塚敬節は「体質 の虚弱な人や老人に多く，下焦（臍より下）に力が 無く, そのために小便が少なく, 上気して痰が多く なり，呼吸促迫する。実際には脈は弦緊洪で腹も全 体に力があって柴胡別甲湯証に似て心下㾂鞕のある ものの方が効果がある。」卓と述べており，心下㾂鞕 や腹満, 軽度の胸脇苦満も本方使用の際のひとつの 指標と考えてよいと思われた。

耳鳴の漢方治療について過去の報告を見ると, 補 腎剂, 柴胡剂, 利水剂, 気剂などの使用が認められ

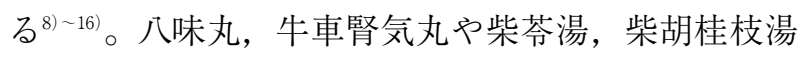
などは症例集積研究がなされており，38.5〜66.7\% の有効率が得られたとされている(表 2$)^{8) \sim 15)}$ 。当 研究所の特色として, 前医で既に何らかの漢方治療 が施され，効果が得られずに受診するケースが比較 的多い点が挙げられる。従って，上述のようなある 程度のエビデンスの得られている方剂を使用してい る症例が当研究所においては比較的少なく, 有效例 も他の報告と比べ少なくなることが予想される。実 際，今回本方が有効であった 5 例のうち, 症例 2 を 含む 2 例がすでに他院にて柴胡剤や補腎剂の投与を 受け無効であった。従って今回このような難治症例
に本方の有効性が示されたことの臨床的意義は大き いと思われる。これまで, 蘇子降気湯の症例報告は 喘息や呼吸困難に対するものがほとんどで'77) 21), 耳鳴に対する使用報告は検索範囲内では認められな かった。以上のことから，気の上衝を伴う耳鳴に対 しては，本方にも応用の価值があると考えられたた め，若干の考察を加えて報告した。

\section{結語}

足冷，気の上衝を伴った耳鳴に蘇子降気湯が奏効 した症例を経験した。数年経過した症例や他の治療 に対し難治性を示す耳鳴にも本方が有効であり，喘 息や呼吸困難などの呼吸器症状以外にも本方の応用 が可能であると考えられた。

附記 本稿は第58回日本東洋医学会総会（広島・ 2007年）に扔いて報告した。

本稿で投与した, 蘇子降気湯加味の構成と生薬集散 地は以下の通りである。

半夏 $(4.0 \mathrm{~g}$, 甘肃省), 紫蘇子 $(3.0 \mathrm{~g}$, 江南省), 陳 皮 $(3.0 \mathrm{~g}$, 静岡県), 厚朴 $(3.0 \mathrm{~g}$, 長野県), 前胡 (3.0 $\mathrm{g}$, 安微省), 桂皮 $(3.0 \mathrm{~g}$, ベトナム), 当帰 $(3.0 \mathrm{~g}$, 奈良県), 大霖 $(2.0 \mathrm{~g}$, 江南省), 采甘草 $(2.0 \mathrm{~g}$, 内蒙 古), 生姜 $(0.5 \mathrm{~g}$, 四川省), 加味生薬: 紫蘇葉 (栃木 県), 附子（四川省）

\section{参考文献}

1）陳師文等撰：和刻漢籍医書集成 増広太平恵民和 剂局方, 67, 北里研究所東洋医学総合研究所医史 文献研究室編, エンタプライズ株式会社, 東京 (1988)

2 ) 孫思㴞：東洋医学善本叢書 第九冊 宋版備中千 金要方(上)，621，オリエント出版，大阪（1989）

3 ) 矢数道明：臨床応用漢方処方解説 増補改訂版, 377-380，創元社，大阪 (1981)

4 ）津田玄仙：近世漢方医学書集成 73 療治経験筆記, 大塚敬節, 矢数道明編, 175-176, 名著出版, 東 京 (1983)

5 ）浅田宗伯：近世漢方医学書集成 96 勿誤薬室方函 口訣, 大塚敬節, 矢数道明編, 256, 名著出版, 東京 (1982)

6 ）大塚敬節, 矢数道明 : 漢方診療医典第 6 版, 368369, 南山堂, 東京 (2001)

7 ) 李時珍, 寺師睦宗訓：臨床百味本草綱目，178, 漢方三考塾, 東京 (1992) 
8 ) 池田勝久, 小林俊光, 伊東善哉, 高坂知節 : 耳鳴 りに対するッムラ大柴胡湯の臨床効果一脂質代謝 との関連一。耳鼻と臨床, 34(2), 535-538（1988）

9 ) 田口喜一郎：難治性耳鳴に対する漢方療法一漢方 薬と西洋薬の単独抢よび併用療法. 難病 - 難治の 漢方療法第 2 集, 現代東洋医学 10 (1) 臨時増刊, 218-220 (1990)

10）西田裕明, 田中康夫, 渡邊健介：自覚的特発性耳 鳴に対する柴朴湯の使用経験。漢方診療，12(5), 23-28 (1993)

11）大西信治郎，澤木修二，土屋幸造，田中洋二，柊 光一, 谷内晶子, 古川政樹, 和田廣巳, 伊藤真郎, 坊野馨二：TJ107 (牛車腎気丸) 多施設共同臨床 試験による耳鳴に対する効果. 耳鼻咽喉科展望, 37(3)，371-379 (1994)

12）岩崎紀子, 坂本守: 耳鳴に対する釣藤散の臨床的 評価. 公立能登総合病院医療雑誌, 12, 28-30 (1998)

13）齋藤晶：頭痛・高血圧を指標とした釣藤散の耳鳴 治療．耳鼻咽喉科臨床，補98：28-30（1998）

14）水田啓介, 伊藤八次, 秋田茂樹, 山田匡彦, 古田 充哉, 早川和喜, 宮田英雄 : 慢性耳鳴に対する柴
胡桂枝湯の効果. 耳鼻咽喉科臨床, 補98, 31-34 (1998)

15）奥野秀次, 根岸達郎：耳鳴に対する牛車腎気丸の 臨床効果．漢方医学，25(3) 18-19（2001）

16）蒲田慶市郎：プライマリーケアに扔ける漢方の役 割, めまい·耳鳴. 漢方と最新治療, $3(1), 31$ 35 (1994)

17）越口栄信：気管支喘息に対する漢方療法一主に蘇 子降気湯を中心として。現代東洋医学, 6 臨時増 刊, 15-18（1985）

18）渡辺一幹：蘇子降気湯に打ける気の考察. 日本東 洋医学雑誌，36，93-94（1986）

19）戸田一成：蘭山医案 咳嗽，東洋医学研究， 101, 32-33 (2001)

20）星野綾美，巽武司，奥裕子，佐藤浩子，伊藤克彦， 小暮敏明：蘇子降気湯と获苓飲の併用が奏効した 咽喉頭違和感と乾性咳嗽の一例. 日本東洋医学雑 誌，58(6)，1121-1126（2007）

21）松田邦夫，稲木一元：『万病回春』の有用処方を 探る 四，蘇子降気湯．漢方の臨床，40(4)，661669 (1993) 